Michał Wagner, PhD, https:/ / orcid.org/0000-0002-2912-9743

Institute of Philosophy

Faculty of Christian Philosophy

Cardinal Stefan Wyszyński University

in Warsaw

\title{
Evolutionary Theism of Henryk Levittoux in the Polish and International Context
}

\author{
Teizm ewolucyjny Henryka Levittoux \\ w kontekście polskim i międzynarodowym ${ }^{1}$ \\ https://doi.org/10.34766/fetr.v48i4.978
}

\begin{abstract}
Henryk Levittoux (1822-1879) is currently best known as the model of Jan Matejko who posed for him as Nicolaus Copernicus. Less known, however, is his concept of evolution, which he presented as a part of his philosophical system and which caused a heated debates among Polish intellectuals in the second half of the nineteenth century. Levittoux's theory, which was trying to combine religious dogma with the achievements of contemporary science, breaks out of the popular historical narrative, in which it is assumed that the discussions about the evolutionism were dominated by creationists and pro-Darwinian positivists. The aim of this article will be to present Levittoux's theory of evolution and to show how he combined the ideas of evolution with the concept of Divine creation. Secondary focus of the article will be to place his theory in the broader context of scientific and philosophical changes, that took place in the nineteenth century. Attention will be paid to the way in which the professionalization of science affected natural philosophers, such as Levittoux, who were refusing to accept the rigorous positivist methodology. It will also be shown how Levittoux's evolutionism became part of the so-called "developmental evolutionism" which promoted a completely different vision of evolution than Darwinism. The non-Darwinian nature of Levittoux's evolutionism was inspired by Étienne Geoffroy Saint-Hilaire's theory. Levittoux adopted his idea that species evolve thanks to the environmental stimulus which affects their ontogenesis. However, this idea will be extrapolated in Levittoux's writings to the whole Earth. So, he will conclude that the Earth is the equivalent of the womb in which, like the fetus, all Life develops. All changes of species, in his opinion, are additionally controlled by a universal principle which he called the law of attractionrepulsion. This law was also the tool by which God created the world. The Levittoux's concept is one of the first attempts to create a synthesis of evolutionism and religious thought in the Polish postDarwinian philosophy of nature. Levittoux, as a continuator of Saint-Hilaire's thought, is also an interesting example of an attempt to instill in Polish philosophy French evolutionist thought.
\end{abstract}

Keywords: Darwin, Evolution, Geoffroyism, Levittoux, Science and Religion, Struve

Abstrakt: Henryk Levittoux (1822-1879) obecnie najlepiej znany jest jako model Jana Matejki, który pozował mu do postaci Mikołaja Kopernika. Mniej znana natomiast jest jego koncepcja ewolucji, którą przedstawił $\mathrm{w}$ ramach swojego systemu filozoficznego i która rozbudziła gorącą dyskusję wśród polskich intelektualistów drugiej połowy XIX wieku. Teoria Levittoux, próbująca łączyć dogmat religijny ze zdobyczami ówczesnej nauki, wyłamuje się ze współczesnej narracji historycznej na temat dziejów ewolucjonizmu w Polsce, zgodnie z którą dyskusja wokół koncepcji przemian gatunków była zdominowana przez antyewolucjonistycznych kreacjonistów oraz prodarwinowskich pozytywistów. Celem artykułu będzie przybliżenie teorii ewolucji Levittoux, ukazanie sposobu, w jaki łączyła ona

\footnotetext{
${ }^{1}$ Artykuł w języku polskim dostępny jest na stronie:

https://www.stowarzyszeniefidesetratio.pl/Presentations0/2021-4Wagne2.pdf
} 
ideę przemian gatunków z koncepcją ich Boskiego stworzenia, oraz osadzenie jej w szerszym kontekście przemian naukowych i filozoficznych, jakie dokonywały się w XIX wieku. Zostanie zwrócona uwaga na to, jak profesjonalizacja nauki wpłynęła na filozofów przyrody takich jak Levittoux, którzy, nie akceptując rygoru metodologii pozytywistów, zaczynali przeciwstawiać się tej nowej wizji przyrodoznawstwa. Ukazane zostanie również, jak ewolucjonizm Levittoux wpisywał się w nurt tzw. „ewolucjonizmu rozwojowego", w ramach którego promowana była zupełnie inna wizja przemian gatunków niż ta, którą promował Darwin. Niedarwinowski charakter ewolucjonizmu Levittoux inspirowany był teorią Étienne Geoffroy Saint-Hilaire'ego, od którego Levittoux przejął ideę, że przemiany gatunków zachodzą dzięki oddziaływaniom środowiska na ontogenezę organizmów. Idea ta zostanie jednak u niego ekstrapolowana na całą Ziemię. Stwierdzi więc, że ziemia jest odpowiednikiem łona, w którym podobnie jak płód rozwija się całe życie na Ziemi. Wszystkie przemiany gatunków będą jego zdaniem dodatkowo kontrolowane przez uniwersalną zasadę, którą nazwie prawem przyciągania-odpychania. Prawo to miało być narzędziem, za pomocą którego Bóg tworzył świat. Koncepcja Levittoux stanowi jedną z pierwszych prób stworzenia syntezy ewolucjonizmu i myśli religijnej $\mathrm{w}$ polskiej postdarwinowskiej filozofii przyrody. Levittoux, jako kontynuator myśli Saint-Hilaire'ego, stanowi również ciekawy przykład próby zaszczepienia w polskiej filozofii francuskiej myśli ewolucjonistycznej.

Słowa kluczowe: Darwin, Ewolucja, Geoffroyizm, Levittoux, Nauka i Religia, Struve

Introduction

In contemporary works devoted to the history of evolutionism, one can increasingly often find postulates about the necessity of departure from the narrative, according to which Darwinism was a widely accepted theory in the nineteenth-century, and the competing concepts were of a religious or philosophical nature (e.g., Ceccarelli, 2021; Delisle, 2017; Ochoa, 2021). A historiography based on such a simple dichotomy distorts history by not fully reflecting the discussions that took place in the context of post-Darwinian biology and philosophy. When reading about the development of evolutionism in the nineteenth-century Poland, it can also be noticed that the historical narrative is often based on two simplifying premises: one stating that Poles did not create any original concept of evolution and limited themselves only to popularizing Western theories (e.g. Konstańczyk, 2015), and that the initial discussions of evolution consisted of a clash between secular and religious perspectives (e.g. Trombik, 2017). However, such an evaluation of the history of Polish evolutionism, as in the case of the international context described by contemporary historians of biology, does not fully reflect the pluralism of opinions and positions that prevailed in the philosophy and natural sciences of that time. In fact, there occurred attempts to create truly original theistic concepts of evolution. And one of them was the theory published in 1869 by Henryk Levittoux. Levittoux (1822-1879) was a physician and naturalist whose name is known today mainly thanks to his older brother, Karol, a conspirator who died tragically in 1841 as a result of self-immolation. Henryk himself left his mark in Polish culture as a model who posed for Jan Matejko when he painted his famous painting "Astronomer Copernicus, or Conversation with God". His philosophy, however, is not widely known, despite the fact that it is an interesting contribution to the discussion on evolutionism in Polish thought. The aim of the article will be to present Levittoux's theory of 
evolution, to show how it combined the ideas of evolution of species with the concept of their divine creation, and to place it in the broader context of scientific and philosophical changes that took place in the nineteenth-century.

Levittoux presented his concept of evolutionism in his 1869 book Zarys filozofii natury (The Outline of the Philosophy of Nature - hereinafter referred to as The Outline or by its full English title). This book was later reprinted under the title Filozofia Natury (The Philosophy of Nature - hereinafter referred to as The Philosophy or by its full English title), and was also published in French, as well as a supplement in the form of a collection of letters published in Paris in 1877. Subsequent editions, growing in volume (from about two hundred pages, The Philosophy of Nature changed into a volume of over five hundred pages) were enriched with further evidence to confirm Levittoux's theses. In an attempt to reconstruct Levittoux's views, I will rely primarily on the first edition of The Outline..., while the later editions and letters will be used to complement some of the theses that the author did not develop sufficiently in his first book. Despite the variety of issues that Levittoux dealt with in his works - such as geology, physics, or chemistry, the article will focus only on the evolutionist themes of his thought.

\section{Henryk Levittoux's philosophy of nature}

Levittoux was a thinker with consistent views and promoted one idea, which was the unification of all fields of science, and more precisely the reduction of all forces operating in nature to one common source. The goal of his work was to create a theory of everything. It is worth stressing here that the nineteenth-century science and philosophy began to depart from creating such complex systems of thoughts, becoming increasingly specialized. The Victorian scientist was no longer required to deal with entire natural world. This scientist should seek answers to specific problems within separate scientific disciplines. This change was especially noticeable in Great Britain, where the word "science" was introduced in order to mark the difference between philosophy and more specialized type of knowledge. The emergence of this nomenclature was used by evolutionists to oppose the so far dominant natural theology, and to promote a new vision of science, the culmination of which was to be Darwinism (Bowler, 2009). This new intellectual movement was noticed by the British intelligentsia, which began to notice the emergence of a new type of thinker. The writer and philosopher Samuel Butler (1878, pp. 31-34) criticized the new caste of scientists that began to undermine recognized dogmas, antagonizing thinkers dealing with classical philosophy and theology. Despite the difficult geopolitical situation, the Polish intelligentsia also noted the emergence of a new intellectual current trying to replace metaphysical reflections with science. One of the first Polish critical approaches to Darwinism O Teorii Darwina (On Darwin's Theory) by Felix Wartenberg from 1866, attacked not only the theory of evolution 
but also empirical sciences (Wartenberg, 1866). Wartenberg (1866, p. 88) stated that science should submit to the principles of metaphysics in order not to create such amoral doctrines as Darwinism. Levittoux, with his "holistic" philosophical program, straddled the line between the reformist postulates of positivists and the traditionalism of metaphysicians. On the one hand, he criticized scientists for abandoning attempts to create a single synthetic theory of reality by focusing only on their disciplines; on the other hand, he realized that the discoveries of empirical sciences could undermine the biblical vision of the creation of the world. Levittoux, wishing to create a theory that would unify the research field of all existing scientific disciplines, decided to rely on the latest discoveries of empirical sciences, stressing that this unification would ultimately aim at demonstrating and honouring God's wisdom (Levittoux, 1869a).

The biblical message was the fundamental point of reference in Levittoux's philosophy and was treated as a kind of yardstick for verifying the correctness of his reasoning. This was partly due to the goal he set for himself while writing The Outline... As he admitted (1874, p. 581) in a polemic with Karol Liebelt, the ultimate goal of his philosophy was to oppose the materialistic philosophy associated with evolutionism and to show how to write scientifically about God and the soul. In his letters, however, he wrote that his greatest achievement was solving the problem of God's relationship to nature, which neither Newton nor Aristotle had been able to cope with (Levittoux, 1877c). This problem, however, was explained with insufficient precision in Levittoux's philosophy. On the one hand, he tries to emphasize the autonomous character of the forces of nature, rejecting interventionism, and on the other hand, he writes that "Nothing shall perish in an eternally alive nature. Nothing shall be lost in general wisdom, in the spirit of the universe whose God is everything; for everything was in God, is in God, shall return to God so that it may live in God forever." (Levittoux, 1869, p. 139). Julian Łapicki, reviewing The Philosophy of Nature for Gazeta Polska, wrote that Levittoux promoted another version of pantheism, and that his whole philosophy was "... the placement his own perceptions within the confines of the revealed religion dogmas ..." (Łapicki, 1869b, p. 3). Interestingly, Levittoux (1869a) himself recognized pantheism as heresy, criticizing Spinoza's philosophy for this very reason. In the response to Łapicki he states (Levittoux, 1874, pp. 549-550) that he is the same pantheist as the theologians who proclaim that God is everywhere.

The theorem of the omnipresence of God, which equated nature to the expression of His will, led Levittoux to conclude that He could be captured by human reason. This, in turn, opened up the possibility of a mathematical approach to divine wisdom, a scientific approach to good and evil, and even to the soul (Levittoux, 1869a; Levittoux, 1874). So Levittoux tried to create a Newtonian science in which every possible aspect of the reality, from the movements of planets on their orbits, to human emotions and ethics, would be captured in the laws of science. This did not mean, however, that his philosophy was an 
expression of scientism criticized by such thinkers as Butler in England or Wartenberg in Poland. Quite the contrary; Levittoux occupied a critical position in relation to the newly established type of science. Despite being openly inspired by the works of Étienne Geoffroy Saint-Hilaire, Jean Pierre Flourens, and Georges Cuvier, Bernard Palissy was the model of a scientist for Levittoux. Mainly known for his artistic work in ceramics, Palissy also became famous as a naturalist, correctly recognizing in the fossils the residue of animal remains, which, as he believed, had died in the flood. For Levittoux, Palissy's discovery, which enabled palaeontology to develop, was an example of the triumph of the scientistpractitioner over the scientific establishment focused on theoretical considerations and not accepting new, revolutionary ideas (Levittoux, 1869a). This criticism of "cabinet researchers" will only become harsher in later editions of The Philosophy... Levittoux would later highlight the role of "artisans" in the development of science even more emphatically - men like Palissy and Christopher Columbus - writing that it was not theorists, but simple people endowed with natural genius that created the foundation of knowledge. The radicalisation of this rhetoric may be partially regarded as a consequence of the unfavourable reception of The Outline ... by the Polish critics. The reviewers saw in Levittoux's work an underdeveloped and unclear lecture on philosophy, which, despite its ambitious objective, was fraught with scientific errors. Particularly severe criticism appeared in Przyroda i Przemyst, one of the most important Polish popular science journals of the time. The reviewer Karol Hertz, being the editor-in-chief of the journal, apart from factual errors, also accused Levittoux of gaps in knowledge: "Leaving aside all the other scientific and logical errors, of which there are many in the work of Mr Levittoux, we shall only draw attention to the fact that whoever wishes to put forward a new theory should first of all be well familiar with everything that has been done before him; secondly, he should demonstrate that his theory explains all known phenomena more easily than the older ones, that it explains unexplained phenomena and, finally, that it leads to new discoveries" (Hertz, 1872, p. 543). In the philosophical sphere, Hertz perceived the reviewed work as rather a "curiosum" and, not wanting to analyse it, wrote that: "We shall omit all mystical and nonsensical terms of Mr Levittoux about the nature of forces and their origins, because such are not available to the normal brain" (Hertz, 1872, p. 542).

For Levittoux, this criticism was an expression of the dogmatic nature of the scientific community which Hertz represented as a teacher, and which did not want to accept new theories. And in his opinion, science needed a new perspective, because despite the fact that scientists wrote, for example, about motion or matter and pointed to the laws that governed them, they were unable to explain their nature or source (Levittoux, 1874). A contradiction may be noticed at this point in the objectives that Levittoux set for scientific work. On the one hand, it requires naturalists to explore the laws governing reality, while fulfilling the Newtonian ideal of science, and on the other hand, by putting forth the above-mentioned 
criticism, he denies this ideal, as if forgetting that Newton himself, departing from hylomorphism, considered the study of the nature of beings as unscientific. This contradiction is explained by Levittoux's methodological project. According to him, the science promoted by positivists and encyclopaedists had become a set of facts that in themselves said nothing about nature, because they lacked philosophical analysis. Philosophy was therefore needed by science to generalize the results of its research. Research work should therefore focus on the inductive method in which scientific facts are generalized within one philosophical system. Thanks to this, not only did science become something more than just an encyclopaedic enumeration of facts, but also philosophy found its confirmation in empirical data (Levittoux, 1874). Levittoux's project was therefore not only a remedy for the state of specific sciences, but also an attempt to revive the philosophy of nature.

Despite praising brilliant practitioners and the necessity of empirical research as the basis for pursuing philosophy - both The Outline... and the later editions of The Philosophy ... did not contain any original observations or experiments on the part of Levittoux. Starting from observations collected by naturalists like Saint-Hilaire and Flourens, Levittoux arrived at his own philosophical conclusions. The criticism of the views of anti-evolutionists such as Cuvier was also theoretical, consisting in showing gaps in their reasoning, and not in showing empirical evidence confirming his own position (cf. Levittoux, 1869a, pp.106-107). This way of conducting research in the nineteenth-century could not have been accepted by the scientific community that focused ever greater attention on experimental and field work, and not on philosophical speculations. Natural sciences, instead of complex philosophical analyses, needed new discoveries and observations. While trying to create his theory of evolution in a way similar to that of Levittoux, i.e., based on the reflections of other scientists, Butler was criticized because, according to reviewers, new scientific theories required new empirical evidence (Butler, 1922, p. 26). Polish positivists had a similar problem with Levittoux's work. The reviewers perceived The Outline... as a compilation work and they accused its author that he had not presented any evidence to support his theses, but merely juxtaposed various, unrelated views of other naturalists (Łapicki, 1869b; Strzemiński, 1869). For Levittoux, however, this criticism was not legitimate. After all, the ultimate goal of his work was not to create another scientific theory, but to conduct a synthesis of the already existing concepts. Therefore, it was necessary to juxtapose the works of various naturalists. Moreover, Levittoux's philosophical method enabled one to notice what scientists, engaged in continuous disputes, were unable to see - that their works complement each other (Levittoux, 1869a, p. 99). For this reason, his synthetic work, bridging the existing scientific and philosophical divisions, could not have resembled a typical scientific project. He said that he could not focus on the analysis of every single fact, as his reviewers wished since his work required a broader, holistic approach, hence it had to be based more on logic than on 
experimental research. According to Levittoux, it was because of this innovative nature that his work had been rejected by the scientific establishment represented by the reviewers criticising it (Levittoux, 1874).

\section{Levittoux's theistic "Geoffroyism"}

As Levittoux wrote (1874, pp. 558-559), he had come up with the idea that species are capable of transformation when he was conducting observations on the ontogenesis in frogs and insects when he was still studying in Warsaw. In addition to his research on ontogenesis, Levittoux, under the influence of his older brother Karol, also became involved in conspiratorial operations, distributing literature forbidden by the occupying authorities. The activities of the so-called "Łuków conspiracy" ended with the arrest of the conspirators in 1840. Henryk, who was left under police supervision, fled to Paris in 1844, where he began medical studies (Kołodziejczyk, 1998). And it was in France that he first encountered evolutionism at the lectures of Isidore Geoffroy Saint-Hilaire, son of the famous evolutionist Étienne (Levittoux, 1874, 559-560). Étienne Geoffroy Saint-Hilaire was a co-creator of the idea of subordination of organs, which he developed with his associate Cuvier. According to Cuvier, God created four immutable types of animal body plan, on the foundation of which modern species exist. Because of this, it was possible to identify analogies in the body plan of different species, as long as they belonged to the same type. Cuvier's theory was antievolutionist in nature - since these types constituted a certain invariable constant of nature, it was impossible for a species to exist and have features being intermediate between various types. Étienne Saint-Hilaire, as a student of Lamarck, argued that these types were derived from one shared organismal design, which in turn indicated the possibility of one species transforming into another (Urbanek, 2007). Despite his affiliations with Lamarck, Étienne Saint-Hilaire developed a theory of transmutation that was substantially different from the one proposed by his teacher. While Lamarck believed that evolutionary transformations are caused by active attempts of organisms to adapt to the environment through what he called the laws of use and disuse, Saint-Hilaire assumed more passive process of transmutation. Organisms did not have to actively strive to develop new characteristics, because the environment itself, influencing them, led to transformations. Another difference between Lamarck and his apprentice was the point at which an organism acquired characteristics. Lamarck stated that due to the nature of the processes of use and disuse, only fully formed organisms were able to modify themselves. However, Saint-Hilaire thought that the process of transformation took place at the beginning of the ontogenesis of an individual, when said individual was still an embryo. Thus, environmental changes - or, more precisely, changes in the atmosphere - affected the embryo, leading to its transformation. That is how species, evolving from a common type of organismal design, led to the creation of the types that 
Cuvier wrote about (Galera, 2021). Following this path, Levittoux stated that not only species arose from one type of organismal design, but also the entire reality arose from one shared beginning.

The theory of evolution, as proposed by the author of The Philosophy of Nature, would therefore be closely related to his philosophy of inanimate nature, in the centre of which he would place an atom. For Levittoux, atoms will be the foundation of all existence, and their movement will be the cause of all changes occurring in nature. Being the constituent elements of reality, atoms would assume a mystical dimension in his works, being the first matter that God created: "An atom is the moment of creating a bond, a type of matter, it is an expressed force, it is the embryo of nature, it is an incarnate word, it is the verbum of Scripture, it is the creation" (Levittoux, 1869a, p. 34). By calling the atom "the word", Levittoux tries to reconciliate the description of Genesis with the contemporaneous physics. For him atoms become material intermediaries with the help of which God creates the world. Hence, in his works the atom is also termed a material concept or the transition of an idea into matter - because it is atoms that bind to each other to create material beings. Atoms become bound to other atoms as a result of a single universal law which Levittoux (1869a, p. 35) calls "the force of attraction in repulsion". This oxymoronic term is a result of the specificity of the functioning of atoms which, depending on the relations they enter into between one another - attraction or repulsion - create other types of beings. Levittoux himself discovered the existence of this force through a thought experiment. As he wrote, if only attraction existed, the atoms would merge into one being and the variety of phenomena noticeable in nature would not exist. If, however, only repulsive forces existed, atoms would not enter into any bonds with each other, and nothing could exist. The force existing in the world must therefore keep all atoms in harmony, simultaneously showing the ability to attract and repulse, so that they can, on the one hand, create solids, and on the other hand, maintain their separateness. There is a constant number of atoms, so the force of repulsionattraction puts them in constant motion, by which they combine and fall apart creating new beings. The idea of one force is an expression of the holistic vision of the world promoted by Levittoux in his works. Nature creates unity, and its harmony is determined by the law of attraction-repulsion. All other forces in nature are only derivatives of this law. Levittoux invokes the metaphor of a prism: just as white light transmitted through it creates a colour palette, attraction-repulsion can manifest itself in nature in the form of many different phenomena (Levittoux, 1869a).

According to Levittoux, the whole living world was created thanks to God, who guided the first atoms to the appropriate trajectory, creating the common ancestor of all animals. "God expressed Himself in matter and as the law of nature, for many centuries active therein (...) He developed it from the atom to man" (Levittoux, 1874, p. 298). The foundation of evolutionary changes was therefore the movement of atoms in accordance 
with the laws of attraction-repulsion, and the evolution itself took place in a way closer to the one described by Saint-Hilaire, that is, through the influence of the environment. However, since Levittoux's goal was to explain the evolution of all life on Earth, SaintHilaire's theory had to be expanded. And so, if changes took place during embryogenesis, then in order to explain the origin and evolution of all organisms, the Earth had to be treated as an analogue of the mother's womb, and the first organism as a developing embryo (Levittoux, 1874). The comparison of the evolution of life to that of embryonic development was also used by Levittoux to formulate hypotheses about the environment of the primeval Earth. So, if a human embryo develops in the warm and humid conditions of the womb, then analogously the first organisms evolved under such conditions. Evolution was therefore embryogenesis on a global scale ${ }^{2}$. The changing environmental conditions led to the differentiation of species and the formation of the currently known taxonomic divisions. While Levittoux assumed that God ultimately controlled the evolution of species, he insisted that His actions were mediated by natural phenomena. At this point, the author of The Outline... referred to Cuvier's catastrophism. According to the catastrophists, the Earth was assailed by global cataclysms which radically changed its shape and led to the extinction of the entire biosphere which God created anew, adapting it to new conditions. Levittoux also believed that environment-changing disasters had occurred throughout the history of the Earth, although they had not been as devastating as Cuvier suggested. Thanks to the natural disasters, the environment changed, which resulted in the emergence of new external factors stimulating further evolution of species (Levittoux, 1869a). These changes had a teleological character. Just like a foetus transforms to acquire the traits of its species, organisms transformed in the course of evolution to acquire their proper form. However, since evolution depended on the environment, when conditions were no longer favourable, some species were unable to complete their process of transformation. Levittoux compares their situation to foetuses that left their mother's womb too early (Levittoux, 1874). Therefore, in nature, alongside perfect species (that is those whose evolution has been completed), such as the human being, there have existed unfinished organisms, i.e., those suspended between various organic types. For example: bats are such unfinished organisms, an intermediate stage between mammals and birds, and zoophytes which are placed between plants and animals (Levittoux, 1869b).

In The Outline... Levittoux adopts the belief, which was common to the natural sciences of the era, that all animals represent different stages of evolutionary development so the evolution of a species will consist of gradual passage through these stages. A similar way of thinking about evolution can be found in the first evolutionists such as Lamarck or Robert Chambers - according to whom the processes of change were inscribed in the great

\footnotetext{
2 It is worth emphasizing that the word evolution was initially used to describe the changes of the
} embryo (Urbanek, 2007). 
chain of being, in which the human being is at the top, being its culmination (cf. Wagner, 2020, pp. 21-24, 43-54). Thus, when the human being began their evolutionary path, they descended from the first common simple organism, and then gradually passed through the animal level, and then the "monkey" level, before attaining the present perfection (Levittoux, 1869a). The problem with this approach to evolution was that it could lead to the recognition of modern species as peculiar "living fossils", that is, past evolutionary forms that had not had the time to transform. So Levittoux, seeing the monkey as one of the stopovers on the way to being human, even wrote in later editions that humans descended from monkeys characteristic of their continent. This view led him to conclusions of a racist nature. And so, he considered dark-skinned people to be descendants of African monkeys (Levittoux, 1874, p. 302), while Asians, Jews, or the inhabitants of India and Brazil to be less developed human forms originating from the antediluvian times (Levittoux, 1869b, p. 210). However, despite these problematic aspects, Levittoux did not proclaim the moral superiority of some human races over others, which distinguished him from the evolutionists of that time.

For Levittoux, the evolutionary path of the human being served as an important reminder of why moral development is so important. As he wrote, despite the fact that the human beings received a soul and a moral sense from God, they could still be demoralized if they surrendered to their animal instincts (Levittoux, 1869a). This combination of demoralisation and devolution also appeared in other nineteenth-century evolutionists and was best expressed by an American palaeontologist Edward Dinker Cope. Trying to reinterpret the biblical message through the prism of the theory of evolution, he wrote about two paths that can be chosen by the human being: the first one was the evolutionary path of moral development, and the second, the path of degeneration consisting in surrendering to primal animal desires. As he wrote (Cope, 1887, p. 169), European culture represents the correct path of evolution, consisting in moral development, while all the others that had not reached its stage of development could be regarded as examples of degeneration. Levittoux, despite racist themes in his philosophy, did not express such radical opinions. For him, all people, regardless of skin colour, had a soul, and thus equal potential for further development or demoralization (Levittoux, 1874). This egalitarianism stemmed from his pacifist beliefs. For Levittoux, wars, exploitation, and even conflicts in the world of science were symptoms of demoralisation that had to be resisted. The way to resist those problems was to live in accordance with God's will, which he identified with Christian doctrine, and in particular with Christ's teachings about the love of one's neighbour. In his exhortation to love and respect, Levittoux was not limited only to humans. In his opinion, the endowment of the human being with a soul by God was to be understood as a part of the evolutionary process in which the soul emerged from a simpler form found in animals. Therefore, human uniqueness was nothing more than an intensification of the natural forces functioning in the nature and had its source in lower organisms (Levittoux, 1869b). Therefore, the humans 
should respect all nature because just as they themselves, it was part of God's act of creation. Everything that came from God, according to Levittoux, deserved equal respect, hence, every person worshiping nature also worshiped God (Levittoux, 1869a).

\section{Reception of Levittoux's thought among Polish intelligentsia}

Levittoux's work was very popular at the time of its publication as one of the few Polish works devoted to issues related to the philosophy of nature. The Outline ... and the later Philosophy... was perceived by the reviewers as an exception in the Polish publishing market - a work that tried to bring something new to science (Hertz, 1872; Łapicki, 1869a, Strzemiński, 1869). However, the positives contained in the reviews stopped right there. The reviewers criticised the book for its incomprehensible and unclear style, inconsistency and contradiction of theses, and even distortion of the views belonging to criticized thinkers (Łapicki, 1869c; Strzemiński, 1869). Levittoux entered disputes with every unfavourable review. The accusatory and direct style of his answers was received unfavourably both by the editorial offices of the journals to which he wrote and the readers themselves. For example, in Przeglad Tygodniowy, a letter by Marian Próchnicki appeared, in which, while commenting on Levittoux's polemic with Julian Ochorowicz, he stated that the author of The Outline ... formulated his arguments so vaguely that the discussion with him was pointless (Próchnicki, 1869). Levittoux $(1869$ e, 118) replied to this letter stating that Próchnicki, as a layperson, should not voice his opinion at all. The reviewer of Biblioteka Warszawska, Bronisław Strzemiński, later commented on the whole matter, saying that the discussions which the author of The Outline... had conducted with the critics incited "disgust and disbelief" $(1869,137)$.

Most often the reviewers were being accused by Levittoux of being biased and incapable of comprehending his work, which meant that they had not noticed its originality (Levittoux, 1869c; Levittoux, 1869d; Levittoux, 1874). However, the issue of the originality of Levittoux's work was raised by the critics. They considered this work derivative; the law of attraction-repulsion was considered to be yet another version of the arche of Ionian philosophers, with the concept of atoms being a continuation of Leucippus's views, and the idea of the unification of forces being derived from a similar concept by Angelo Secchi (Łapicki, 1869b; Strzemiński, 1869; Próchnicki, 1869). Neither was the work considered to be original in the context of Polish science. According to Eapicki, the idea that all phenomena can be reduced to the operation of a single law was presented earlier in Józef Supiński's Myśl ogólna fizjologii powszechnej (The General Thought of Universal Physiology), who had applied it to social sciences. However, it is worth taking a closer look at this objection raised by Łapicki. So, in his work, Supiński (1883, pp. 265-266) writes that all existing laws of nature can be reduced to two opposing forces of projection and decay, which in turn determine the 
relations taking place in societies. In Levittoux there also appears the theme of recognizing interpersonal relations as the resultant of the laws of attraction-repulsion, although it is not developed to the same extent as in Supiński's. The author of The Outline... does not conduct an in-depth analysis of the exact relationship between the primordial law of nature that he postulated and social dynamics. He only suggests the possibility of such research, limiting himself to the statement that living in accordance with these laws guarantees happiness and peace in the world (Levittoux, 1869b). Therefore, Łapicki's assessment seems to be exaggerated in this case. But comparing Levittoux's works to the philosophy of Henryk Struve caused greater controversy.

Józef Kraszewski paid attention to the similarities between the views of Levittoux and Struve while commenting on the publication of the Levittoux's letters in France. The text he published in Biesiada Literacka was positive and did not accuse any of the authors of plagiarism (Kraszewski, 1877). Levittoux, however, responding to Kraszewski, stated that the views presented by Struve in Synteza dwóch światów (A Synthesis of Two Worlds) constitute a plagiarism of his ideas, which he had presented earlier in The Outline... (Levittoux, 1877a). The similarity between Struve and Levittoux was said to consist mainly in the similarity of the thesis on the relationship between God and nature. In Synteza ... Struve formulates a research goal similar to Levittoux's - he attempts to reconcile the materialism represented by scientists and positivists with the idealism of Christian philosophers. Struve neutralizes this dispute partly by proclaiming that God, being omnipresent, is also part of the world. Materialists are right proclaiming the existence of certain permanent laws of nature as they are a manifestation of God's presence in the world. While idealists are right proclaiming the existence of something more than matter - because ultimately the world is a reflection of God's mind (Struve, 1876). Levittoux saw a repetition of his views in these theses, of which he accused Struve on the pages of Biesiada Literacka, and later, when it decided not to publish his polemics, on the pages of Wiek i Echo (Levittoux, 1877a; Levittoux, 1877b; Levittoux, 1877d). Struve responded to these allegations by stating that Levittoux, without knowing the history of philosophy, appropriated theses that had been known for years. As he wrote: "... to put it shortly, one needs to be devoid of any clarity of perception to seriously convince oneself that the above sentence about the relationship of God to nature is the author's invention ..." (Struve, 1877, p. 3). Analysing the theses of Struve and Levittoux, it is difficult to agree with the allegations of plagiarism. Levittoux did not precisely define the principle of God's relation to the world created by Him. In Struve's writings, it is clearly delineated: the world, being for God only an expression of His mind, enters into a relationship with it, one being similar to that which the human being has with their own thoughts (Struve, 1876). Levittoux, in an attempt to prove Struve's guilt, relied on passages from his Listy (Letters)... 
as evidence of plagiarism (Levittoux, 1877d) 3 . There, he wrote, as did Struve, that God, being omnipresent, does not exist on any separate plane of existence. The problem, however, is that Listy (Letters)... were published after the A Synthesis... And taking into account that Levittoux had not made such a thesis before, one should rather suppose that it was he who had borrowed this thesis from The Synthesis ... and not the other way around.

Some of the reviewers, however, did notice the originality of Levittoux's work. Julian Ochorowicz published an exceptionally positive review in Przeglad Tygodniowy. He praised the originality of the work, calling The Outline ... "a valuable acquisition for our scientific literature" (Ochorowicz, 1869, p. 37). Ochorowicz viewed Levittoux's work an attempt to acquaint Polish conservatives with recent scientific discoveries by masking typically positivist ideas and theories with religious language (Ochorowicz, 1869). The assessment of the intentions of the author of The Outline ... was obviously wrong, as Levittoux himself pointed out to Ochorowicz (Levittoux, 1869c). Ochorowicz's conclusion as to the motivations behind Levittoux's evolutionary theism is better understood in the context of the then prevailing disputes between evolutionists and religious circles. This dispute quickly took on an ideological character and divided Polish intellectuals into pro-evolutionary liberals and socialists speaking in favour of positivism, and anti-evolutionary conservatives associated with classical philosophy (Konstańczyk, 2015). Attempts to synthesize both approaches were not too frequent, and even, as Ochorowicz's example shows, difficult to imagine. Hence, it was easier to consider Levittoux's synthetic approach a ruse in a discussion with creationists than a sincere attempt to create a theistic reinterpretation of the concept of evolution. However, Levittoux's ideas were also appreciated by people looking for ways to reconcile religion with science. Antoni Skórkowski, writing for Przyroda $i$ Przemyst, who also proclaimed the possibility of cognising the nature of God through the intermediary of natural sciences (Skórkowski, 1881), referred to The Outline ... in his article "Geneza miłości (The Genesis of Love)". Levittoux's theses served as a confirmation of his own idea of the universality of love as the law of nature, which was of similar character to the forces of attraction-repulsion (Skórkowski, 1880). It is also known that Levittoux's reflections became the basis for at least one popular science lecture devoted to demonstrating the compliance of

3It is worth adding that there were real philosophical differences between Struve and Levittoux. Listing all of them is beyond the scope of this article, but one of the most important ones is their approach to matter. As Struve $(1877,14-15)$ pointed out, he himself saw in it a kind of abstraction of the human mind, while Levittoux believed in its reality.

${ }^{4}$ Of course, Levittoux was not the only Polish thinker trying to combine evolution with religious thought. Back in 1860, Adam Chałupczyński tried to create a theistic theory of evolution. Later, after the publication of The Outline..., there were also voices denying that Darwin's theory was atheistic, among others, Henryk Hoyer (1895), Antoni Skórkowski (1881) and Bronisław Rejchman (1882) wrote about it. Ochorowicz's reaction does not show that attempts at synthesis did not exist at all, but that they were extremely rare in the 1860s. In later years, with the calming down of the first reactions to evolutionism, an increasing number of voices appeared in support of the possibility of reconciling evolutionism and religion. 
the biblical narrative with the present state of science, as reported by the journal Wiarus (Krajewicz, 1874).

\section{Levittoux's evolutionism in the context of post-Darwinian biology}

Still, one can ask how Levittoux's theory of evolution fared in an international context? This question is problematic because Levittoux's evolutionism is difficult to classify. The most obvious category that can be assigned to him is "Geoffroyism", but it also raises some problems. In accordance with Ernst Mayr's definition, this trend was characterized by emphasizing the role of environmental influences on the transformation of species and was part of a wider evolutionary current - neo-Lamarckism. Neo-Lamarckism, an extension of Lamarck's theory, was one of the most important trends in the nineteenth-century evolutionary biology. Although neo-Lamarckism arose as an alternative to Darwinism, the scholars supporting this trend incorporated the mechanism of natural selection into their theories, assigning it a secondary role in the processes of evolution compared to the more important mechanism of use and disuse (Mayr, 1982). The problem with calling Levittoux a "Geoffroyist" in Mayr's sense is that he did not accept any of the then popular evolutionary mechanisms. He rejected both the mechanisms proposed by Lamarck (Levittoux, 1869a, pp. 151-152) and Darwin, formulating accusations against him whereby natural selection, being a process of elimination, could not have caused the development of new features (Levittoux, 1869b, pp. 441-442). Neither did he accept the inheritance of acquired characteristics (wrongly assigning the authorship of this concept to Darwin) - relying on the anecdotal argument about the non-inheritance of talents among people (Levittoux, 1869b, pp. 449-450). Thus, Levittoux's theory does not fit in with the neo-Lamarckian trend and thus also with Mayr's "Geoffroyism" either, precisely by rejecting most of the characteristic theses of this trend. Levittoux's philosophy should rather be described as true "Geoffroyism" because, unlike other nineteenth-century theories that fell into this category, it was fully based on the original thought of Saint-Hilaire (cf. Wagner, 2020, pp. 76-81). Moreover, his theory may be considered as "universal Geoffroyism" because he applied the principle of passive transmutational transformations of the embryo to every sphere of reality. Not only the development of species was treated by him as analogous to ontogenesis. Levittoux also saw a reflection of individual development in the development of the Earth, treating, for example, cataclysms as counterparts of the diseases of an organism (Levittoux, 1869a). Thus, he created one universal evolutionary model for both animate and inanimate nature.

The problem with the classification of Levittoux's theory stems from the fact that he did not present any hypothetical mechanism of evolution. In The Outline... he lists three possible reasons for evolution: the first one, which he rejected as impossible, was hybridization, the other two were related to the action of the internal forces of an organism, 
which were supposed to cause a gradual or abrupt transformation. According to Levittoux (1869a), these forces were also responsible for ontogenesis. Here we can ask the question: how the same force was responsible for both the development of the individual and for the evolution of the species? Levittoux does not answer this question. In his opinion, evolution just happened by itself under the right conditions. This approach resembles the popular theory of orthogenesis at the turn of the 20th century. Orthogeneticists also stated that evolution is a natural phenomenon dependent on the internal "growing-force" which living organisms possess. And while Levittoux did proclaim the existence of immanent forces responsible for change, the difference between him and the orthogeneticists lay in the role they assigned to the environment. When it comes to orthogenesis, the constantly evolving species was influenced by the changing environment, which led to its adaptation (Wagner, 2020). For Levittoux, evolution was not about adapting to the environment, it was simply triggered thereby. Hence, in The Outline... we will not find any speculations about the adaptation of species to the environment. The lack of interest in the phenomenon of adaptation explains why Levittoux did not offer any proposal of an evolutionary mechanism in his work. Since evolution was nothing more than a variant of ontogenesis, it was impossible to talk about adaptations, as the changes in the individual followed a certain predefined plan and were not related to the requirements of the environment. The lack of interest in the issue of adaptation was later reflected in the way Levittoux criticized other evolutionists. And so, he considered Adam Chałupczyński as only an inept continuator of Darwin's thought, while Darwin himself, whom he considered Lamarck's continuator, was accused by him of deliberate concealment of his inspiration drawn from Saint-Hilaire in order to appropriate his ideas (Levittoux, 1869b). This criticism was obviously unfounded and demonstrated Levittoux's disorientation in his contemporaneous evolutionary biology. Chałupczyński did accept natural selection, but he saw it as one of the many evolutionary laws (he listed as many as seven), which applied only to the most developed species (Chałupczyński, 1880). On the other hand, Darwin's theory, based on the operation of natural selection, was significantly different from the concepts of Lamarck and Saint-Hilaire, in which this mechanism did not occur. Levittoux, disregarding the mechanism of transformation, treated all evolutionary theories as equal without noticing the differences setting them apart. In this context, we may wonder if his support of Saint-Hilaire's theory was merely an arbitrary choice. And if it was not, since he was not interested in the mechanisms of evolutionary changes, what was his decision based on?

Of course, it can be hypothesized that Levittoux was so inspired by the lectures of Isidore Saint-Hilaire that he accepted his father's theory as the only correct one without questioning it. And while this hypothesis is probable, the specificity of Levittoux's views indicates another factor that might have influenced him. Although Levittoux returned to Poland in 1855, thus omitting the French discussion of Darwinism, he still drew his principal 
scientific knowledge from works written in French. This influence is evident, for example, in how he equates Darwinism to a variety of Lamarckism, but also in his lack of interest in evolutionary mechanisms. French evolutionists were reluctant to delve into the study of evolutionary mechanisms, considering it an endeavour beyond the capabilities of the scientific method. This was due to the popularity of positivist philosophy and experimental methodology promoted by the most important figures of French science of that time - Claude Bernard and Louis Pasteur. French scientists took no interest in the study of the mechanisms of transformation until the 1920s (Herring, Loison, 2017). It is understandable that Levittoux did not delve into these issues in the 1860s. Levittoux probably adopted methodological beliefs from the French as well. So, when he criticized Darwin's experiments on pigeons, stating (Levittoux, 1869b, p. 444) that he had not presented the changes of the species but only the formation of breeds, he followed the methodology of French zoology that required unequivocal experimental evidence of the transformation of one species into another. Of course, at this point it can be stated that in this respect "Geoffroyism" should not be treated as a theory consistent with this methodological standard either. Still, the French evolutionists possessed a more inclusive idea of experiment and extended its meaning to observation as well. The theses put forward on the basis of observations could therefore be considered experimental if they were reached through scientific, e.g., hypothetical-deductive, reasoning (Herring, Loison, 2017). In this sense, Saint-Hilaire, who based his theory on the analyses of the body plan of various animal species, might have appeared as a researcher who provides better scientific arguments for transmutationism than Darwin who worked solely on pigeon breeds.

Levittoux, despite the fact that he created his works in Poland, continued the French tradition. And just like Saint-Hilaire, who compared the body plan of various animals to demonstrate their common design, Levittoux also compared the achievements of contemporary science to build a theory of "everything" from them. That is why he could have seen himself as another brilliant practitioner like Palissy, because, ultimately, his work was not based on theorizing, but on observation and comparison, that is, it was in line with the standards of the methodology applied in French zoology. Hence, he was able to write that "So, in my book (i.e. Philosophy of Nature - author's remark), by close observation of the analogy and relationship between the most diverse phenomena of all nature, that is, by explaining scientific facts which are the fruit of close observation throughout the ages in a proper way (...) I have arrived, in my view, at the solution to the mystery of the mechanism of the universe"(Levittoux, 1874, p. 452). 


\section{Conclusions}

Publishing The Outline of the Philosophy of Nature Levittoux approached his work with enthusiasm. He believed that he contributed considerably to the development of knowledge and that it would bring him posthumous fame, "Should the light of recognition come, may it bestow its blissful gifts on my beloved children, let it be a memento of their loving father, his last fondness for his fellow human beings and the deepest reverence for the Creator." (Levittoux, 1869a, p. 18). However, this enthusiasm left him after the first reviews and numerous disputes with critics. In the last editions of his Philosophy... he wrote in a more pessimistic tone: "Summarizing my life's work in The Outline of the Philosophy of Nature, I thought that I would achieve something for humanity, that my compatriots would learn something from it. - I was disappointed: because instead of recognition, I merely exposed myself to continuous attacks from all sides" (Levittoux, 1874, p. 521). In a posthumous note published in Tygodnik Ilustrowany in honour of Levittoux, the editors primarily wrote about him as a doctor who fought against homeopathy and tried to use the latest achievements of medicine in his own practice. His book was not mentioned because, as the editors wrote, an obituary was not a place where one should judge the philosophical significance of the deceased person's writings. However, the following comment was made: "... we must however recall that it stirred up commotion and stimulated many minds to explore philosophical questions that had hardly ever been addressed before" (Jenike, 1879, p. 162). The Outline... was therefore remembered as an original and controversial work. The question is how we should assess it from our modern perspective.

Levittoux's works fit in the trend of evolutionism at the turn of the 19th and 20th centuries, which Peter Bowler (1988) called "developmental evolutionism". As he noted, some post-Darwinian naturalists were not able to fully understand and accept the theory of natural selection, hence they resorted to pre-Darwinian concepts. It also resulted in a number of evolutionary theories competing with Darwinism, such as neo-Lamarckism and orthogenesis. These theories, representing "developmental evolutionism", were characterized by the assumption of the teleological nature of evolutionary processes. Levittoux's evolutionism shared these traits with them, so it may be qualified to belong to the same trend of non-Darwinian transmutationism. An additional feature that Levittoux shared with the creators of the "developmental" trend was the medium through which he expressed his views. Non-Darwinists, unable to fully express their views on evolution in specialist journals, published their theses in popular science literature. Therefore, influential neoLamarckists and orthogeneticists, such as Edward D. Cope and Theodore Eimer, wrote easyto-digest books for laymen - most often illustrating their views with easy-to-understand comparisons from everyday life or school physics and mathematics. In this manner, they 
were able to popularize their views, bypassing the obstacle of the Darwinist-dominated scientific community (Ulett, 2014). We can discern similar elements in Levittoux's work. The Outline... was a combination of well-known scientific facts, reinterpreted through the prism of the author's personal beliefs. On the other hand, where Levittoux encountered problems with explaining how the laws he proposed operated, he referred to simple metaphors, comparing, for example, the laws of attraction-repulsion to wars, alliances or feelings of love and hate (Levittoux, 1869a; Levittoux, 1874). Ultimately, these attempts at popularization did not have much effect, and in the literature of the time only a few positive references to Levittoux's philosophy may be found. Therefore, his theory was hardly a ground-breaking one from the perspective of modern science. From a historical perspective, however, it deserves attention for two reasons: first, it is an interesting case of "Geoffroyism" breaking out of simple Mayr's description, who saw in this trend only a fraction of neo-Lamarckism to which Levittoux's theory certainly did not belong; secondly, Levittoux's evolutionism, belonging to the trend of "developmental evolutionism", shows a broader context of the discussion on the theory of evolution in Poland, which in the literature on the subject was most often reduced to a simple division into Darwin's supporters and his opponentscreationists. The case of Levittoux shows that by looking once again at the history of evolutionism in Poland and going beyond this simple dichotomy, one can find Polish representatives of the non-Darwinian trend of "developmental evolutionism".

\section{Bibliography:}

Bowler P.J. (1988). The non-Darwinian revolution. Reinterpreting a historical myth, Baltimore London: The Johns Hopkins University Press.

Bowler, P.J. (2009). Popular Science, (in:) P.J. Bowler, J.V. Pickstone (eds.), The Cambridge History of Science. Vol. 6: The Modern Biological and Earth Sciences, 622-634, New York: Cambridge University Press, https:/ / doi.org/10.1017/CHOL9780521572019.

Butler, S. (1878). Life and habit, London: Trubner.

Butler, S. (1922). Luck, or cunning as the main means of organic modification?, London: Jonathan Cape.

Ceccarell,i D. (2021). Recasting Natural Selection: Osborn and the Pluralistic View of Life, (in:) R.G. Delisle (ed.), Natural Selection, 171-191, Cham: Springer, https:// doi.org/10.1007/978-3-030-65536-5.

Chałupczyński, A. (1880) O niektórych błędach w teorii Darwina, [On some flaws in Darwin's theory], Przyroda i Przemyst, 37, 439-441.

Cope, E.D. (1887). The origin of the fittest. Essays on evolution, New York: D. Appleton and Company.

Delisle, R.G. (2017). From Charles Darwin to the Evolutionary Synthesis: Weak and Diffused Connections Only, in: R. G. Delisle (ed.), The Darwinian Tradition in Context. Research 
Programs in Evolutionary Biology, 133-167, Cham: Springer,

https:// doi.org/10.1007/978-3-319-69123-7.

Galera, A. (2021). Étienne Geoffroy Saint-Hilaire and the First Embryological Evolutionary Model on the Origin of Vertebrates, Journal of the History of Biology, 54, 229-245, https:// doi.org/10.1007/s10739-021-09638-5.

Herring, E., Loison, L. (2017). Lamarckian Research Programs in French Biology (1900-1970), in: R. G. Delisle (ed.), The Darwinian Tradition in Context. Research Programs in Evolutionary Biology, 243-269, Cham: Springer, https://doi.org/10.1007/978-3-31969123-7.

Hertz, K. (1872). Przegląd Piśmiennictwa Polskiego [Review of Polish Literature], Przyroda i Przemyst, 45, 542-543.

Hoyer, H. (1895). Obecne zapatrywania przyrodników na tak zwaną teorię Darwina, [Current views of naturalists on the so-called Darwin theory], Wszechświat, 47(XIV), 737-742.

Jenike, L. (1879) Doktor Henryk Levittoux, [Dr. Henry Levittoux], Tygodnik Ilustrowany, 194 (VIII), 161-162.

Kołodziejczyk, A. (1998) Życie i śmierć Karola Levittoux (1820-1841) w świetle źródeł historycznych i legendy, [The life and death of Charles Levittoux (1820-1841) in the light of historical sources and legend], Niepodległość i Pamięć, 2 (12), 53-67.

Konstańczyk, S. (2015). Recepcja teorii Darwina w filozofii polskiej XIX wieku, [Reception of Darwin's theory in Polish philosophy of the 19th century], (in:) K. Bylica, R. Kilian, Piotrowski, D. Sagan (eds.), Filozofia - nauka - religia, 409-426, Zielona Góra: Oficyna Wydawnicza Uniwersytetu Zielonogórskiego.

Krajewicz, F. (1874). W Towarzystwie Przemysłowym w Poznaniu miał wczoraj p. Kozłowski odczyt o "morzu", [Yesterday, at the Industrial Society in Poznań, Mr. Kozłowski had a lecture on "the sea."], Wiarus. Pismo Średniego Stanu Polskiego, 134, 23.

Kraszewski, J. (1877) Listy z Zakątka, [Letters from the corner], Biesiada Literacka, 88 (IV), 149150.

Levittoux, H. (1869a) Zarys filozofii Natury, [Outline of the philosophy of Nature], Warszawa: W drukarni Gazety Polskiej.

Levittoux, H. (1869b). Filozofia Natury, [Philosophy of Nature], Warszawa: W drukarni Gazety Polskiej.

Levittoux, H. (1869c). Polemika naukowa, Przegląd Tygodniowy. Życia Społecznego, Literatury i Sztuk Pięknych, 9, 72-75.

Levittoux, H. (1869d). Polemika naukowa, [Scientific polemic], Przeglad Tygodniowy. Życia Społecznego, Literatury i Sztuk Pięknych, 9, 117-118. 
Levittoux, H. (1869e). Polemika naukowa, [Scientific polemic], Przegląd Tygodniowy. Życia Społecznego, Literatury i Sztuk Pięknych, 14, 117-118.

Levittoux, H. (1869f). Odpowiedź na krytykę pana Bronisława Strzemińskiego zamieszczoną w zeszycie IV Biblioteki Warszawskiej, za kwiecien 1869, [A response to the criticism of Mr. Bronisław Strzemiński included in the notebook of the Fourth Warsaw Library, for April 1869], Biblioteka Warszawska. Pismo poświęcone naukom, sztukom i przemystowi, 2, 326-334.

Levittoux, H. (1874). Filozofia Natury, [Philosophy of Nature], Warszawa: W drukarni Gazety Lekarskiej.

Levitoux, H. (1877a). List dr. Levittoux, [Letter of dr. Levittoux], Biesiada Literacka, 92 (IV), 223.

Levitoux, H. (1877b). Korespondencja z miasta [Correspondence from the city], Wiek. Gazeta polityczna, literacka i społeczna, 240.

Levittoux, H. (1877c). Lettres à un ami sur quelques questions fondamentales du domaine de la philosophie de la nature, Paris: F. Savy, Libraire-Editeur.

Levittoux, H. (1877d). Replika Dra Levittoux, Echo, 249, 9-10.

Łapicki, J. (1869a). Literatura Bibliografia i krytyka, (Filozofia Natury), [Literature Bibliography and Criticism. (Philosophy of Nature)], Gazeta Polska, 165, 2-3.

Łapicki, J. (1869b). Literatura Bibliografia i krytyka, (Filozofia Natury), [Literature Bibliography and Criticism (Philosophy of Nature)], Gazeta Polska, 169, 2-3.

Łapicki, J. (1869c). Literatura Bibliografia i krytyka, (Filozofia Natury), [Literature Bibliography and Criticism (Philosophy of Nature)], Gazeta Polska, 170, 2.

Mayr, E. (1982). The growth of biological thought. Diversity, Evolution, and Inheritance, Cambridge - London: The Belknap Press of Harvard University Press.

Ochoa, C. (2021). The Origins of Theoretical Developmental Genetics: Reinterpreting William Bateson's Role in the History of Evolutionary Thought, (in:) R.G. Delisle (ed.), Natural Selection, 137-170, Cham: Springer, https://doi.org/10.1007/978-3-030-65536-5.

Ochorowicz, J. (1869) Przegląd Literatury Polskiej, [Review of Polish Literature], Przeglad Tygodniowy. Życia społecznego, Literatury i Sztuk Pięknych, 5, 36-37.

Próchnicki, M. (1869) Korespondencje od i do Redakcji, [Correspondence from and to the Editorial Office], Przegląd Tygodniowy. Życia społecznego, Literatury i Sztuk Pięknych, 12, 104.

Rejchman, B. (1882). Teoria Darwina w stosunku do nauki i życia - szkic ogólny, [Darwin's theory in relation to science and life - general outline], Ateneum, 27 (3), 510-527.

Skórkowski, A. (1880). Geneza miłości, [The genesis of love], Przyroda i Przemyst, 36, 425-427.

Skórkowski, A. (1881). Idea Boga w brzaskach XX-go wieku [The idea of God in the dawn of the 20th century], Przyroda i Przemyst, 52, 613-615. 
Struve, H. (1876). Synteza dwóch światów. Szkic filozoficzny, [A synthesis of two worlds. A philosophical sketch], Warszawa: Nakładem Gebethnera i Wolffa.

Struve, H. (1877). Odpowiedź Henryka Struve na pretensje Pana Levittoux, [Henryk Struve's answer to the claims of Mr. Levittoux], Warszawa: W drukarni Jana Noskowskiego.

Strzemiński, B. (1869). "Zarys filozofii natury” przez Henryka Levittoux, ["An Outline of the Philosophy of Nature" by Henry Levittoux], Biblioteka Warszawska. Pismo poświęcone naukom, sztukom i przemystowi, 2, 136-142.

Supiński, J. (1883). Pisma, [The scriptures], Warszawa: Nakład Gebethnera i Wolffa.

Trombik, K. (2017). Stefana Pawlickiego i Władysława Zaborskiego polemika z darwinizmem (1872-1886), [Stefan Pawlicki and Władysław Zaborski polemic with Darwinism (1872-1886)], Teologia i Człowiek, 37 (1), 109-121, http:/ / dx.doi.org/10.12775/TiCz.2017.006.

Ulett, M.A. (2014). Making the case for orthogenesis: The popularization of definitely directed evolution (1890-1926), Studies in History and Philosophy of Biological and Biomedical Sciences, 45, 124-125, http:/ / dx.doi.org/10.1016/j.shpsc.2013.11.009.

Urbanek, A. (2007). Jedno istnieje tylko zwierzę... Myśli przewodnie biologii porównawczej, [There is only one animal ... Key thoughts of comparative biology], Warszawa: Muzeum i Instytut Zoologii PAN.

Wagner, M.J. (2020). Interpretacje rozwoju biologii ewolucyjnej na przełomie XIX i XX wieku, [Interpretations of the development of evolutionary biology at the turn of the 19th century], Warszawa: Wydawnictwo Liberi Libri, https:// doi.org/10.47943/lib.9788363487478.

Wartenberg, F. (1866). O Teorii Darwina, [About Darwin's Theory], Poznań: W komisie księgarni M. Leitgebra. 